\title{
Financing of Healthcare Facilities in Pension System Assets of Ecologically Problematic Regions in Kazakhstan
}

\author{
Aigerim YESSENTAY', Anel A. KIREYEVA ${ }^{2}$, Madina KHALITOVA ${ }^{3}$, Nazerke A. ABILKAYIR ${ }^{4}$
}

Received: February 25, 2020 Revised: March 08, 2020 Accepted: June 10, 2020

\begin{abstract}
The purpose of the study is a theoretical and practical justification for building a mechanism for financing health facilities based on publicprivate partnerships from a pension fund in regions with environmental problems. The theoretical background is built on works of local and foreign authors on state and non-state pension provisions issues, pension funds' assets management. This study provides an analysis of the health status of the population of the Kyzylorda region; it analyzes also the worldwide and Kazakhstan practice of investing pension funds and implementing projects. There has been legislative and methodological framework for financing health projects based on public-private partnerships in Kazakhstan. The scientific methods considered in this study made it possible to develop a mechanism for financial support for the modernization of a healthcare facility using the budget of pension funds. The authors point out possible risks in the implementation of projects in the field of healthcare and make recommendations on the construction a mechanism for financing healthcare facilities in the regions of Kazakhstan with environmental problems. In addition, they underline the key insights of the analysis, which are requisites for identifying the profitability of project for business and social effects for the public. Factors influencing efficacy, effect and implementation risks identified.
\end{abstract}

Keywords : Finance, Investment, Pension Provision, Funds' Assets Management, Healthcare, Economic Growth, Kazakhstan

JEL Classification Code: G10, G20, J32

\section{Introduction}

Financial crisis and poor economic efficiency of investment had an impact on public sector pension scheme. Presently, for stimulating the development of the pension system and reprieving government budget duty

\footnotetext{
${ }^{1}$ First Author. PhD Student, The joint educational program of Kazakh National University al-Farabi and Institute of Economics of the Ministry Education and Science of RK, Kazakhstan. E-mail: aigera588@mail.ru

${ }^{2}$ Corresponding Author. Chief Researcher, Institute of Economics of the Ministry of Education and Science of the Republic of Kazakhstan [Postal Address: 29 Kurmangazy Street, Almaty, 050010, Kazakhstan] E-mail: anele19@mail.ru

${ }^{3}$ Chief Researcher, Institute of Economics of the Ministry of Education and Science of the Republic of Kazakhstan, Kazakhstan. E-mail: madinakhalidi@mail.ru

${ }^{4} \mathrm{PhD}$ Student, KSPH, Almaty, Kazakhstan. E-mail: abilkaiyr. nazerke@gmail.com

(c) Copyright: The Author(s)

This is an Open Access article distributed under the terms of the Creative Commons Attribution Non-Commercial License (http://Creativecommons.org/licenses/by-nc/4.0/) which permits unrestricted noncommercial use, distribution, and reproduction in any medium, provided the original work is properly cited.
}

on the maintenance of pension funds, ways to increase the investment component of pension savings is needed, as well as implementation of a public-private partnership in these sectors. New public management (NPM) is the domain paradigm in the subject of public administration (Barberis, 1998), as well as promoting the policy, which includes market orientation of state services, contracting and privatization (Kalimullah, Alam, \& Nour, 2012). Public-private partnerships (PPP) have been an area of particular interest as a new tool to support the provision of public services. For example, many developed countries have started taking actions on economic liberalization in view of significant untapped potential in the health sector and adoption of incentive tools for distressed developing regions.

Rapid population aging in the world is an historical trend. Given the fact that expenses for pension and healthcare are positively correlated with rise in incomes, aging, urbanization and the transition from infectious diseases to diseases provoked by an unhealthy lifestyle, the management of these costs is a serious problem. There are many interrelationships between health care and pension agreements, in terms 
of cost, risk exposure, and mutual influence on important environmental decisions.

Environmental problem solving in regions should be a goal achievements in the field of diagnostics and innovations in science and medical technology. This suggests that it will take substantial resources to manage the costs of aging (Kapsali, 2011; Kireyeva, Abilkayir, \& Tsoy, 2018). Nevertheless, as the population of many Asian countries is aging while remaining at relatively low incomes, this poses serious problems for Asian governments to finance health care and expenses for pension. Rapid aging in the Asian economy carries consequences, not only for financing the cost of healthcare and pension provision for a growing number of old people, but for the wider economy and society, for example, employment and consumption patterns, the ability to generate and absorb technologies, transport systems and voting schemes. Therefore, it is evident that Asia will have a significant impact on the dynamics of world demographic trends.

Scientific problems related to health improvement under the condition of environment pollution, and justification for a system to improve the health of the population today are the priority tasks of the state's environmental policy of developed and developing countries. Casual relationships between environmental changes and the health status of the population have become apparent and require preventative treatment measures. The problem of population health improvement is essential both due to the exacerbation of environmental disadvantages over the past decades, and due to the complex control over this process.

Emerging negative trends in the field of ecology and environment have acquired special significance for Kazakhstan. For the population of the Kyzylorda region, these issues are especially relevant, as risk factors involved with environmental degradation are part of the landscape. For example, in the Kyzylorda region today, there is a difficult situation regarding the provision of drinking water, not only in rural areas, but in the cities as well. The main indicator of the problem in Kyzylorda city as regards healthcare is high overall incidence of health problem in the population; the Republic of Kyzylorda occupies the 7th place in the country on this measure. The overall morbidity of the population by groups shows that the Kyzylorda people gets sick and seeks medical help in connection with diseases of the respiratory, circulatory and digestive systems.

Environmental issues have clearly affected the state of health of the local people due to the spread of diseases, such as tuberculosis, anemia, diseases of the genitourinary system, pathology of pregnancy and childbirth, and hypertensive disorders. The region has a high infant mortality rate. Therefore, the health status of the population there requires immediate actions to provide quality medical services throughout the region. The implementation of some state-run programs contributes to a better ecology of the region and reduces the incidence of diseases. The theoretical background for this research is informed by the work of local and foreign scholars on issues of state and non-state pension provisions, and pension funds assets management.

The study is divided into the following sections. Section 2 introduces the theoretical framework of the economic growth and sustainable development. Section 3 explains the methodology. Section 4 presents the results of this research. Section 5 offers concluding thoughts.

\section{Literature Review}

Among different factors that influence the state of the population health, according to World Health Organization data, the shared contribution of the environmental component does not exceed 20-30\%. Nevertheless it must be considered that the majority of current human diseases arise out of environmental pressure. The negative effect of the environment in the context of massive techno genic development leads to a demographic decline, a degradation of body defense, and an incidence on the mortality rate. Environmental pollution of the air, water, soil and foodstuffs can have great consequences on health such as cancer, respiratory and cardiovascular diseases, among others. (Israel, Schulz, Estrada-Martinez, Zenk, Viruell-Fuentes, Villarruel, \& Stokes, 2006; Weinhold, 2011; Awuor \& Melles, 2019).

Over the years of reforms in practices around the world, a substantial experience has been accumulated in the social development of the economy based on mutually beneficial partnerships between the state and business. European countries and governments around the world have engaged in private sector participation in development, financing, and the provision of public infrastructure and services (Maynard, 1986; Zheng, Roehrich, \& Lewis, 2008; Mahoney, McGahan, $\&$ Pitelis, 2009). Their proponents argue that by contributing to increased diversity and competition, such "partnerships" provide better infrastructure and services with an "optimal" distribution of costs and risks (Kwak, Chih, \& Ibbs, 2009).

Although public-private partnerships can be defined relatively simply, as "a long-term contract between the private party and the public institution for the provision of a public asset or service in which the private party carries significant risk and managerial responsibility", in practice, there are differences based on segregation of duties and risk between factors of the public and private sectors. This study focuses on public-private partnerships defined as business models for related infrastructure and services, with the exception of public-private partnerships for drug research, where private sector contributions are more charitable. However, the mechanical transfer of international practice is limited by developmental challenges of the economy, in 
the event of a crisis, investment activity and other factors. Therefore, the mechanism of public-private partnership seems most attractive for both the state and the pension system, which is currently very limited in investment tools.

When deciding on the implementation of national PPP programs, a holistic approach should be taken that conceptualizes public-private partnerships as a whole and recognizes the dynamic complexity between the main agents contributing to the system. To solve the problems arising from the implementation of public-private partnerships, it is necessary to look at a holistic perspective that takes into account a number of social factors, especially public trust and satisfaction.

Under the capitalist structure of the economic system, the history of interaction between the state and business went through two main stages. In the first stage, the main task of entrepreneurship was to get rid of various forms of coercion by the feudal state to fulfill their own interests. However, the state paid attention to socio-economic processes, which had impact on the business sector.

According to institutional theory, a large role in the implementation of sociological projects is assigned to state monopolies. The theory of the public sector is being developed and the state has begun to perform a number of functions related to the economic interaction of the state and business. There is a great struggle between two trends under current conditions. One is the unity of democracy and the capitalist market, and other is the acceleration of the institutionalization of social life and the economy. With the development of civil society, as well as during periods of deep social and political transformations, the social responsibility of both the state and private sector intensifies. Publicprivate partnerships have become very popular institutional arrangements, as they are perceived as a salvation compared to the lack of dynamism in the provision of traditional public services (Jamali, 2004). Public-private partnership presents working agreements, based on mutual long-term co-operation between public sector organization outside the public sector (Bovaird, 2004). For example, private organizations can partner with non-governmental organizations to design and execute cyber security operations; or they design, build, finance, support and operate infrastructures and facilities for the people (Brinkerhoff \& Brinkerhoff, 2011). The private sector can supposedly provide services more efficiently than the public sector (Joha \& Janssen, 2010).

In recent years, in many countries worldwide, government at all levels has been increasingly attracting private business, its funds and organizational capabilities to solve the strategically important tasks of developing the economy and society, as well as solving environmental problems and the consequences of environmental disasters. Under condition of effective management, such partnership between public and private sectors (PPSMP) can help to increase resource utilization, reduce costs and drive innovations (Samaddar, Nargundkar, \& Daley, 2006; Schemm \& Legner, 2008; Salman \& Jamil, 2017; Kireyeva, Lakhonin, \& Kalymbekova, 2019)

The economic basis of the constitutional system includes concepts of economic interaction between each other, and with other members of society or government. Hence, the economic interaction are been carried into effect within a legal framework, consequently, the government has a certain impact on entrepreneurs, as well, to ensure stable and harmonious development of an individual, society and state. Public-private partnership (PPP) represents the combination of all society resources (state, municipal, private) managed on a long-term and mutually beneficial basis for the creation of public goods (landscaping, development of social and engineering infrastructure) or the provision of public services (in the field of health, education, social protection, etc.)

This is an institutional and organizational alliance between the state in the person of government and business for the implementation of socially significant investment and innovative projects for the country. As a rule, projects in the field of social sphere, infrastructure, and ecology are the most significant for society, but they are not profitable for sale on the market due to their low profitability and return ability, and no tangible effect. The effect of publicprivate partnerships is achieved by combining the efforts and capabilities of public authorities and business resources. In addition, such a partnership, on the one hand, allows to act on equal and mutually beneficial conditions, and on the other hand, to share powers, responsibilities and risks.

\section{Research Methods}

Suggested methods of research aims at the possibility to use pension system assets in the recovery of the population in ecologically problematic regions. For this purpose, in this study, there are the scientific methods used. Taking into account the generalization and system analysis of existing theories and finance models, investment opportunities of institutional investors, in particular pension funds are considered. Scientific methods enable the study and design of theoretical approaches on financing socially significant projects. In scientific research as a whole, the available data using theoretical analysis will allow us to investigate and systematize the application of general scientific methods (Kireyeva, 2016; Chulanova, Satybaldin, \& Koshanov, 2019). In relation to this study, the following methods are used:

1) Institutional approach. It involves the study of the legislative and legal support of the investment process, the presence and operation of market institutions, as well as an information base. In the investment process, the institutional approach ensures the effective operation of the investment 
vehicle, the elements of which must interrelate and interact. The institutional approach is used for political and economic process analysis. In this case, the institutional approach is applied as the tool for the justification of practical methods of investment, in the current public-private partnership for the implementation of projects in the field of healthcare, with involvement of social, legal and economic institutions;

2) Organization and economic approach. It is applied to find options and organizing the most acceptable investment mechanism, taking into account the existing institutional base. In our scientific studies, we use the ecological and economic approach to create a matrix to conjugate foundations for the direction of decarbonization;

3) Systematic approach. It is used to study risks, which can arise during projects implementation. Application of this approach is required for systemization and quality risk assessment. This is important in the framework of the suggested approach, as it is a question of investment of pension assets, for which impact of risks should be minimal.

The initial theoretical background of this research is the results of academic research work of local and foreign scientists in the field of social investment. Application of the suggested methods has led to design a theoretical and methodological approach to achieve the target goal in a comprehensive manner.

\section{Analysis and Results}

\subsection{Analysis of the Incidence of the types of Disease on the Population in the Kyzylorda Region}

An analysis of the incidence of the types of diseases on the population in the Kyzylorda region has been carried out. The classification of the population morbidity profile in the Republic of Kazakhstan differs from generally accepted method elsewhere in the world (for example, diabetes is not considered separately, but is included in the class of "endocrine diseases"). In Table 2, there is data on general incidence of the population of the Republic of Kazakhstan from 2010-2015 years by disease classes per 100,000 people (hereinafter referred to as incidence per 100,000 people, unless otherwise indicated) are presented in descending order. The first four in the Republic of Kazakhstan include diseases of the respiratory system, circulatory system, digestive system and genitourinary system (see Table 1).

For reference, among the no-communicable diseases in the world, the four main diseases are cardiovascular diseases, cancer (neoplasms), diabetes and chronic lung disease. These diseases are affecting disproportionately countries at low and medium levels of development. There, the four diseases account for three quarters ( 28 million) of all deaths in the world in 2012. As regards death by non-
Table 1: The total incidence of the population of the Republic of Kazakhstan by classes of disease per 100,000 people

\begin{tabular}{|l|c|c|}
\hline \multicolumn{1}{|c|}{ Diseases class } & $\mathbf{2 0 1 7}$ & $\mathbf{2 0 1 8}$ \\
\hline TOTAL, Disease & 52031.5 & 52410.7 \\
\hline Diseases of the respiratory system & 21573.0 & 22018.8 \\
\hline Diseases of the circulatory system & 2394.7 & 2429.7 \\
\hline Diseases of the digestive system & 3671.0 & 3840.1 \\
\hline $\begin{array}{l}\text { Diseases of the genitourinary } \\
\text { system }\end{array}$ & 3420.6 & 3852.3 \\
\hline $\begin{array}{l}\text { Complications of pregnancy, } \\
\text { childbirth and the puerperium }\end{array}$ & 5067.5 & 3722.2 \\
\hline Eye disease & 2334 & 2363.9 \\
\hline $\begin{array}{l}\text { Diseases of the blood, blood- } \\
\text { forming organs }\end{array}$ & 2169.0 & 1963.0 \\
\hline Diseases of nervous system & 1884.8 & 1871.5 \\
\hline $\begin{array}{l}\text { Diseases of the musculoskeletal } \\
\text { system and connective tissue }\end{array}$ & 1503.4 & 1631.7 \\
\hline Endocrine diseases & 923.0 & 875.9 \\
\hline Skin diseases & 2635.1 & 2565.1 \\
\hline Injuries and poisoning & 3493.2 & 3270.4 \\
\hline Infectious and parasitic diseases & 1540.2 & 1428.1 \\
\hline Ear diseases & 1455.1 & 1558.3 \\
\hline Mental disorder (substance use) & 241.5 & 216.4 \\
\hline Mental disorder & 58.9 & 55.0 \\
\hline Neoplasm & 498.8 & 563.4 \\
\hline Congenital malformations & 60.8 & 82.0 \\
\hline
\end{tabular}

communicable diseases, cardiovascular diseases $(46 \%$ of all non-communicable diseases), neoplasms (22\%), and respiratory diseases $(10.5 \%)$ are leading.

The morbidity of the population of the Republic of Kazakhstan is characterized by the so-called "double burden" of incidence; in addition to non-communicable diseases, the incidence of infectious diseases is also relatively high (see Table 2).

Nevertheless, according to the data, there is a decrease in the overall incidence for certain classes of diseases in the country and in the regions, both in the Republic of Kazakhstan and in the Kyzylorda region. The morbidity rate is also reduced according to the "first recorded cases" parameter, that is, the rate of spread of diseases.

The incidence of diseases registered for the first time in the Kyzylorda region showed that most Kyzylorda people get sick and seek medical help in connection with:

- Diseases of the respiratory system;

- Diseases of the digestive system; 
Aigerim YESSENTAY, Anel A. KIREYEVA, Madina KHALITOVA, Nazerke A. ABILKAYIR /

Journal of Asian Finance, Economics and Business Vol 7 No 7 (2020) 531 - 541

Table 2: Morbidity patterns (the number of diseases registered for the first time in life) in the Kyzylorda region by disease classes per 100,000 people, 2017-2018.

\begin{tabular}{|l|c|c|}
\hline \multicolumn{1}{|c|}{ Diseases class } & $\mathbf{2 0 1 7}$ & $\mathbf{2 0 1 8}$ \\
\hline $\begin{array}{l}\text { Diseases of the respiratory } \\
\text { system }\end{array}$ & 16500.0 & 16836.9 \\
\hline Diseases of the digestive system & 6389.2 & 6264.1 \\
\hline Diseases of the blood & 4860.4 & 4450.7 \\
\hline $\begin{array}{l}\text { Diseases of the genitourinary } \\
\text { system }\end{array}$ & 4027.9 & 4200.6 \\
\hline Injuries and poisoning & 2988.7 & 2813.2 \\
\hline $\begin{array}{l}\text { Diseases of the skin and } \\
\text { subcutaneous tissue }\end{array}$ & 2408.2 & 2562.5 \\
\hline Eye disease & 2485.0 & 3373.3 \\
\hline Diseases of nervous system & 2634.8 & 2972.3 \\
\hline Circulatory diseases (CD) & 2420.8 & 2362.4 \\
\hline Ear diseases & 2076.0 & 2016.3 \\
\hline Infectious and parasitic diseases & 1555.3 & 1308.1 \\
\hline $\begin{array}{l}\text { Musculoskeletal and connective } \\
\text { tissue diseases }\end{array}$ & 1406.1 & 1468.4 \\
\hline Endocrine diseases & 1134.0 & 1271.6 \\
\hline Mental disorder. (substance use) & 245.0 & 193.1 \\
\hline Neoplasm & 221.3 & 210.9 \\
\hline $\begin{array}{l}\text { Congenital malformations and } \\
\text { chromosomal abnormalities }\end{array}$ & 157.8 & 187.2 \\
\hline Mental disorder & 50.5 & 50.2 \\
\hline
\end{tabular}

- Blood disease;

-Which is not characteristic of other regions of Kazakhstan;

- Diseases of the genitourinary system;

- Injuries, poisoning, which is also not characteristic of other regions of Kazakhstan.

Further, according to a decreasing incidence rate, skin and subcutaneous tissue diseases, eye diseases, nervous system diseases, circulatory system diseases, ear diseases are noted.

Data on morbidity dynamics, in general, in all types of morbidity are ambiguous. Thus, diseases with congenital anomalies, endocrine diseases, eye diseases, etc., have increased. The analysis has shown that this trend is not applicable to all classes of diseases with statistically insignificant fluctuations

Data on Kyzylorda city in the context of the main classes of causes of death indicate a coincidence of the origin of death in the region and the city: the diseases of the circulatory system are leading $-22-25 \%$ of the causes of death, respiratory organs $10-14 \%$ - then, death due to respiratory diseases, accidents, and diseases of the digestive system. Myocardial Infraction (MI) and cerebrovascular accident (CVA) are represented in one category in the statistics of Kazakhstan CD (Circulatory diseases), whereas in the world statistics, they are categorized separately. In the origin of morbidity and mortality in the Republic of Kazakhstan, in the Kyzylorda region and in the city of Kyzylorda, the same diseases are leading in the number of all cases (both for the first time and chronically) as in the world morbidity structure: MI (Myocardial Infraction), oncological disease (neoplasms), CVA (cerebrovascular accidents). In the statistics of Kazakhstan, MI (Myocardial Infraction) and CVA (cerebrovascular accidents) are in the same category as $\mathrm{CD}$ (Circulatory diseases).

If we consider the geographical location of existing public and private outpatient clinics, including urban diagnostic center and regional medical center of Kyzylorda region, there is obviously a lack of competitors in the cities where new clinics would be expected. Marketing research points out the necessity of standard Municipal Policlinic according to a territorial logic of 400 attendances per shift. The data indicated that, there is requirement for additional medical aid in the form of outpatient care clinic with such departments as therapy, family medicine, pediatrics, cardiology, oncology, gastroenterology, surgery and traumatology, urology, gynecology.

\subsection{Behavior of Pension System Assets of Kazakhstan.}

Amid the global financial crisis, the government of Kazakhstan has taken a decision on pension funds scheme modernization to facilitate industrialization of Kazakhstan in the following directions. According to the new reform, the state established a Unified Accumulated Pension Fund (UAPF) for the purpose of regulating investors pension accounts. The authorized body regulating the activities of the UAPF is the National Bank of the Republic of Kazakhstan. In May 2014, the National Bank Board approved the UAPF Investment Declaration.

Since 2016, the strategy of UAPF pension assets investment has been changed, and the functions of UAPF pension assets regulations have been delegated to the National Fund Management Council of the Republic of Kazakhstan. According to the UAPF Investment Declaration, a list of financial instruments of assets permitted for investment has been stated in 2016 by the National Bank in accordance with National Fund Management Council recommendations. It was tasked to increase foreign currency portion of pension assets. Portfolio currency diversification broadens the scope of investment and the range of financial instruments acquired 
through pension assets Entering new foreign markets allows improving the quality of the investment portfolio and increasing its liquidity.

Further investment strategy for pension assets will be aimed at diversifying investments in various financial instruments and issuers. Attracting foreign companies is part of the ongoing efforts to diversify the portfolio and reduce risks (see Table 3).

According to the National Bank data, the total investment of pension assets in the banking sector in 2014 amounted to KZT900 billion, in 2015, KZT392 billion, and KZT112.8 billion in 2016. In 2017, UAPF pension assets were not invested in second-tier banks. In 2014-2015, UAPF pension assets were invested in bank deposits and bonds. As a result, the amount of pension assets invested in some banks exceeded $250 \%$ of their capital. From the beginning of 2016 to May 22, 2017, the share of the banking sector of Kazakhstan decreased from $33,9 \%$ to $25,3 \%$ of the
UAPF pension assets. The decrease in the concentration of pension assets in banks was mainly due to a reduction in new investments, as well as planned repayments by banks of their obligations. As can be seen, the structure of the investment portfolio does not fundamentally change. This trend has been developing almost since the formation of the funded system. Assets placed inside the economy are significant only due to the volume of government securities. In 2018, the profitability of the UAPF investment portfolio was $11,27 \%$, while inflation was $5,3 \%$.

In the context of forced industrialization of Kazakhstan, the development of internal investment market is needed, including the market of derivative security to improve UAPF investment opportunities. This problem is particularly relevant in light of the discussion of financial interests on the issue of transferring pension assets to private management companies while maintaining a single accounting function of UAPF.

Table 3: The structure of the investment portfolio of UAPF RK

\begin{tabular}{|l|c|c|c|c|}
\hline \multicolumn{1}{|c|}{ Type of financial tool } & $\begin{array}{c}\text { Current value in } \\
\text { billion KZT per } \\
\mathbf{0 1 . 0 1 . 2 0 1 7}\end{array}$ & in 2017 & $\begin{array}{c}\text { Current value in } \\
\text { billion KZT per } \\
\mathbf{0 1 . 0 1 . 2 0 1 8}\end{array}$ & in 2018 \\
\hline $\begin{array}{l}\text { State Securities of the Republic } \\
\text { of Kazakhstan }\end{array}$ & 2 910,82 & $43,51 \%$ & 3587,63 & $46,14 \%$ \\
\hline $\begin{array}{l}\text { State Securities of Foreign } \\
\text { States }\end{array}$ & 365,01 & $5,46 \%$ & 948,84 & $12,20 \%$ \\
\hline $\begin{array}{l}\text { International Financial } \\
\text { Institutions }\end{array}$ & 86,63 & $1,29 \%$ & 172,55 & $2,22 \%$ \\
\hline $\begin{array}{l}\text { Corporate bonds of issuers of } \\
\text { the Republic of Kazakhstan }\end{array}$ & 84,03 & $1,26 \%$ & 58,3 & $1 \%$ \\
\hline $\begin{array}{l}\text { Bonds of quasi-state } \\
\text { organizations of the Republic of } \\
\text { Kazakhstan }\end{array}$ & 900,17 & $13,46 \%$ & 791,68 & $10,18 \%$ \\
\hline $\begin{array}{l}\text { Bonds of second-tier banks of } \\
\text { the Republic of Kazakhstan }\end{array}$ & 1450,20 & $21,68 \%$ & 1246,49 & $16,03 \%$ \\
\hline $\begin{array}{l}\text { Corporate bonds of foreign } \\
\text { issuers }\end{array}$ & 137,92 & $2,06 \%$ & 62,74 & $0,81 \%$ \\
\hline $\begin{array}{l}\text { Shares and depositary receipts } \\
\text { of issuers of the Republic of } \\
\text { Kazakhstan }\end{array}$ & 127,46 & $1,91 \%$ & 184,14 & $2,37 \%$ \\
\hline $\begin{array}{l}\text { Shares and depositary receipts } \\
\text { of foreign issuers }\end{array}$ & 18,33 & $0,27 \%$ & 23,68 & $0,30 \%$ \\
\hline $\begin{array}{l}\text { Deposits of second-tier banks of } \\
\text { the Republic of Kazakhstan }\end{array}$ & 399,91 & $5,98 \%$ & 325,82 & $4,19 \%$ \\
\hline Derivative instruments & 0,00 & $0,00 \%$ & 277,41 & $3,57 \%$ \\
\hline Repurchase Agreement & 0,00 & $0,00 \%$ & 11,02 & $0,14 \%$ \\
\hline Finances and other assets & 177,54 & $2,65 \%$ & 59,01 & $0,64 \%$ \\
\hline
\end{tabular}


Analyzing investment policies for pension funds, most of the literature on finance is concentrated on the usage of average and deviations of investment returns to measure effectiveness. For example, Randall and Satchell (1997) compare the performance of various asset portfolios of a pension fund with respect to average values and variance of income. The advantage of this analysis is the ability to use standard tools for analysis of the average deviation developed by Markowitz.

The disadvantage however, is that it does not take into account that pension funds experience serious losses when returns are low. Owadally and Haberman (2004) minimize a quadratic measure of the variability of the contribution and the market value of assets. Randall and Satchell (1997) have noticed that pension funds cannot afford 'to lose a huge amount of money, even if they often earn small amounts of money.' This asymmetry is not taken into account by the model, which is determined only by the average value and deviation.

Worldwide pension funds invest part of their assets in government bonds of their countries. Many countries allow their pension funds to invest in various financial assets. Investments in the shares of large, highly rated companies, mutual funds, real estate and other highly profitable assets are in high demand in countries with a reliable and developed financial system and prudent supervision. In addition to a stable, long-term flow of portfolio and direct investment, such investments in the economy make it possible to increase the return on work of solid capital concentrated in pension funds. Pension funds with the ability to diversify their investments have real annual returns higher than the average country portfolio of assets.

The preference for pension funds investment is fixed yield securities investment, especially in government securities, which minimize risk.

\subsection{The Investment Mechanism of Interaction between the State and Business in the Investment and Post-investment Periods}

When choosing forms of implementing public-private partnerships in the healthcare sector, it should be highlighted that the state carries out its regulatory role in three main areas:

- Firstly, it develops a strategy and principles on which the relations of local authorities, business and society are built;

- Secondly, it forms the institutional environment for implementing partnerships with business;

- Thirdly, it is engaged in the selection of forms and methods of partnership with business, organizes it and determines implementation mechanisms.
The most specific here is the last direction, as each project has its peculiarities and therefore needs selection process of forms and methods to account for different characteristics. Sometimes the implementation of a project requires the transformation or improvement of legal and regulatory frameworks in furtherance of private and public sectors.

Therefore, in the research, we will consider the direction to determine partnership mechanism. First, we suggest the concept of public-private partnership project regulation modernization of healthcare facilities, participants of publicprivate partnership project and their functions, the order of their interactions

Since the National Fund Management Council regulates the investment of pension fund assets, their participation through the stock market requires the preparation of a legal framework and maximum protection against risks. Long-term assets of future pensioners act as the investor. Therefore, the concept must be well thought out, as much as possible, at the same time investments must be protected from all types of risks. Kazakhstani practice has not been tested for the mechanism of issuing securities for projects in healthcare. Consequently, the first period is needed at the stage of introducing this kind of financing of the economy.

It should be noted that Kazakhstan is legally quite prepared to attract pension assets through the stock market for social projects. Over the past 10 years, the country has changed the rules on the securities market and tax base, adopted laws in the field of concession law and publicprivate partnerships, and brought the budget into line. So, in 2005, the first Kazakhstani infrastructural bonds were issued for the construction of the new railway station "Stantsiya Shar-Ust-Kamenogorsk".

As the issuer of new securities, there was specially created concession company Doszhan Temir Zholy", whose main shareholder is IFC. Nevertheless, in the beginning of 2009 , the concessionaire was not able to pay out coupons on bonds due to problems arising from the financial crisis. In late 2009, the government put forward a proposal to transfer infrastructure bonds to a state guarantee to attract pension funds

To determine the effectiveness of the project, it is necessary to conduct a marketing research that includes the following items:

- analysis of morbidity in the region;

- analysis of current and predicted (for the period of the public-private partnership project implementation) demand conditions for services resulting from the implementation of a public-private partnership project;

- analysis of volumes, types and prices of services that are provided taking into account the current situation in the industry (region) by consumers' categories; 
- analysis of competition in the medical services market, analysis of the unmet needs of the population for medical care on an outpatient basis;

- analysis and justification for a certain acceptable (socially fair) unit price of a service, including analysis of the willingness and ability of potential consumers to purchase a unit of service (pay for a unit of service) as part of a publicprivate partnership project;

- analysis of the project provision with specialists of relevant qualifications.

Key conditions for successful project implementation are:

the use of mechanisms to create the investment attractiveness of the project;

assistance of central and local executive bodies in the implementation of the project;

determination of the order and conditions of activity of a private partner in the process of operation and maintenance of the facility;

creation of an effective financial model with the identification of sources of cost recovery and income of a private partner.

A private partner operates and maintains a public-private partnership project, fulfills obligations to ensure compliance of a public-private partnership with established technical and operational indicators during the whole agreement period of public-private partnership. Upon the expiration of the PPP agreement, the PPP object will be consigned to state ownership.

The following mechanism of interaction between the parties, the responsibility of each side of the public-private partnership of the project, including third parties in the investment period, is presented in table 4.

Functions, obligations, responsibilities and risks of project participants in the investment period must be highlighted: the local executive body proposes to implement the project based on public-private partnership. Its functions include monitoring the implementation of the project and

Table 4: Participants of the public-private partnership project in the investment period

\begin{tabular}{|l|l|}
\hline $\begin{array}{l}\text { Public } \\
\text { Partner }\end{array}$ & $\begin{array}{l}\text { Local executive body (Akimat), as well as } \\
\text { the state body authorized by it to conclude } \\
\text { a public-private partnership agreement }\end{array}$ \\
\hline $\begin{array}{l}\text { Private } \\
\text { Partner }\end{array}$ & $\begin{array}{l}\text { Private Entrepreneur, Public-Private } \\
\text { Partnership Agreement based on direct } \\
\text { negotiations. }\end{array}$ \\
\hline $\begin{array}{l}\text { Private } \\
\text { Partner } \\
\text { Founder }\end{array}$ & $\begin{array}{l}\text { Provides financing from equity for a private } \\
\text { partner to fulfill obligations under a public- } \\
\text { private partnership agreement. Manages } \\
\text { bond issues. }\end{array}$ \\
\hline
\end{tabular}

organizing the provision of co-financing. The participation of state bodies in the form of the provision of state support measures in accordance with the law.

\subsection{Risk Management in Financing Modernization of Health Facilities through a Public-Private Partnership Mechanism: Identification and Prevention Measures}

Risk analysis is an important element of the decisionmaking process. The implementation of the public-private partnership of the project is associated with the risk of losses, the causes of which may be risks, including commercial, social, economic, technical and financial. To avoid or reducing the threat of losses, the task of risks identification is needed, as well as early actions taken to prevent them. The process of risks identification consists of three stages: risk identification, probability and damage estimation, defining activities of risk control and reduction.

Risk identification takes place through analysis of external and internal factors that may affect the project. Damage and risk probability are assessed by applying statistical and financial formulas and analyzing the situation as a whole.

Identification of risk reduction is possible by analyzing specific measures and actions, the implementation of which leads to a decrease in the probability or damage of the risk, or its complete disappearance.

Based on the peculiarities of the development of the Kyzylorda region as a region with environmental problems, we attempted to determine the kinds of risks that may arise when implementing a project to finance the modernization of a healthcare facility through public-private partnerships and classify them into following main categories:

- risks at the stage of project implementation;

- risks at the stage of operation of the facility.

We have conducted an expert risk assessment of the partnership project for the modernization of the healthcare facility and obtained the following results (see Table 5).

\section{Conclusions}

The modern economy of Kazakhstan requires sustainability, especially in budget funds. On the other hand, the environmental condition of most regions of Kazakhstan requires special attention in improving the public health in the first place.

Above proposed models can be put to good use where there are road maps for regions with the lowest level of socioeconomic development and environmentally problems, as well as providing compulsory health insurance. For instance, the Government of India, to rectify this situation, adopted 
Aigerim YESSENTAY, Anel A. KIREYEVA, Madina KHALITOVA, Nazerke A. ABILKAYIR /

Journal of Asian Finance, Economics and Business Vol 7 No 7 (2020) 531 - 541

Table 5: Results of expert risk assessment during the implementation of the clinic modernization project

\begin{tabular}{|c|c|c|c|c|}
\hline \multirow[t]{2}{*}{ Title of risk groups } & \multirow[t]{2}{*}{ Risk title } & \multirow[t]{2}{*}{ Without prejudice } & \multicolumn{2}{|c|}{ Average } \\
\hline & & & $\begin{array}{l}\text { Probability } \\
\text { estimation }\end{array}$ & $\begin{array}{l}\text { Damage } \\
\text { evaluation }\end{array}$ \\
\hline \multirow{2}{*}{ Institutional risks } & $\begin{array}{l}\text { State refusal to reimburse operating } \\
\text { expenses of a private partner as a } \\
\text { result of a significant budget deficit }\end{array}$ & Investments & $2 \%$ & $7 \%$ \\
\hline & $\begin{array}{l}\text { State refusal to provide co-financing } \\
\text { to a private partner in the result of } \\
\text { legislative changes. }\end{array}$ & Investments & $2 \%$ & $6 \%$ \\
\hline \multirow{4}{*}{$\begin{array}{l}\text { Financial and } \\
\text { economic risks }\end{array}$} & $\begin{array}{l}\text { Full or partial suspension of project } \\
\text { financing by a private partner and, as } \\
\text { a result, the inability to complete the } \\
\text { construction of the Object. }\end{array}$ & $\begin{array}{l}\text { Fail to receive } \\
\text { predicted profit }\end{array}$ & $9 \%$ & $9 \%$ \\
\hline & Project fund rising absence & Investments & $8 \%$ & $15 \%$ \\
\hline & Interest-rate risk & $\begin{array}{l}\text { Loan interest } \\
\text { amount }\end{array}$ & $4 \%$ & $10 \%$ \\
\hline & Exchange risk & $\begin{array}{l}\text { Additional } \\
\text { expenses for } \\
\text { building and } \\
\text { installation works } \\
\end{array}$ & $18 \%$ & $7 \%$ \\
\hline \multirow[t]{2}{*}{ Social risks } & $\begin{array}{l}\text { Injury that could result in death, } \\
\text { temporary or permanent disability of } \\
\text { workers in work-related matters, and } \\
\text { the possible loss of the bread-winner } \\
\text { of the construction worker's family }\end{array}$ & Salary & $3 \%$ & $2 \%$ \\
\hline & $\begin{array}{l}\text { Workers' strike as a result of violation } \\
\text { of their rights (untimely payment of } \\
\text { wages, large-scale dismissals) }\end{array}$ & Salary & $3 \%$ & $2 \%$ \\
\hline $\begin{array}{l}\text { Project specific risks } \\
\text { (contractual risks) }\end{array}$ & $\begin{array}{l}\text { The risk of a private partner providing } \\
\text { poor-quality work on the maintenance } \\
\text { of the building, equipment, as well as } \\
\text { failure to conduct repairs or untimely } \\
\text { repairs }\end{array}$ & $\begin{array}{l}\text { Fail to receive } \\
\text { predicted profit }\end{array}$ & $5 \%$ & $9 \%$ \\
\hline
\end{tabular}

the program of health insurance "Rashtriya Swasthya Bima Yojana" (RSBY) in 2008. RSBY was a national framework of health insurance, launched by the Ministry of Labor and Employment (MO) for families below the poverty line (BPL) in informal economy, to improve access to secondary health care and provide financial protection from financial losses and debts, because of health problems related to hospitalization (Peters \& Muraleedharan, 2008).

Road maps must be mainstreamed; this is first the level of income, poverty incidence, issues of investment climate, economic growth, and issues of unemployment. Also, the solution of a number of complex issues that hinder the development of certain regions must be tackled.

In general, this is the modern social and economic policy of our country. We are to do everything so that the regions develop at a faster pace and provide them with full support, so that the level of development of the regions, per capita incomes, are aligned in all of Kazakhstan. This is the strategic objective. It is immersed in all national projects and must be addressed.

In the context of economic policy implementation, these models can be used in a mixed way. Investigation of the possibilities of implementing public-private partnership projects in the field of healthcare showed their viability. It should be noted that this area is not new and there is already a legal framework and certain practical experience. Projects of Private-Public Partnership have been developed in the energy sector in most countries. However, involving the private sector in the implementation of projects in the social sphere is rather difficult and requires a more thorough 
justification, both financially and institutionally. Thereupon we have considered precisely these sectors both from the viewpoint of an organization and its risks.

The model of Private-Public Partnership refers to contract concessional schemes and are used depending on the application area. In the field of services, construction of clinics and technical and technological modernization of the healthcare sector, the following models are possible:

- operator model- transfer to management;

- cooperation model, as it is usable in industries where services are not well defined and therefore cannot be depreciated;

- concession model is used in the implementation of long-term projects;

- contractual model is used in projects where investments are focused on reducing current costs;

- rent and property lease;

- service contract;

- leasing model is used in technical and technological modernization, as well as buildings construction.

Broadly, we have defined the key insights of the analysis, which are requisites for identifying profitability of project for business and social effect for the public; we have identified factors, which influence the efficacy, effect and implementation risks. The fact that there is a medical institution with small capacity of 400 attendances per shift shows the possibility of its implementation in other regions concerning peculiarities of its development, which is ecological, geographical, economic, natural and climatic, demographic etc.

Attention to the issue of risk prevention is related to the fact that some of them are identical and can arise regardless of region, territory, or area, while others take place due to regional differences, which determines the need for the risk classification, given in the study. The effect of external factors has meaningful influence on economic functions that are associated with rapid emergence of exchange and interest rate risks. This aspect is also important while executing the project of a social nature. We emphasize that financial risks are most important, and it results in the expert risk assessment. In the context of insufficient financial resources, the concept introduced is relevant and can be applied virtually in accordance with the provided model with consideration to tax and customs legislation. It also reflects what requirements are needed for improving the legislation to raise financial resources, knowledge and professionalism of private entrepreneurship in the implementation of state projects in the social sphere and the distribution of state functions in society.

\section{References}

Awuor, L., \& Melles, S. (2019). The influence of environmental and health indicators on premature mortality: An empirical analysis of the City of Toronto's 140 neighborhoods. Health \& Place, $58,102-155$.

Barberis, P., (1998). The new public management and a new accountability. Public Administration, 76, 451-470.

Bovaird, T., (2004). Public-private partnerships: from contested concepts toprevalent practice. International Review of Administrative Sciences, 70(2), 199-215.

Brinkerhoff, D.W., \& Brinkerhoff, J.M., (2011) .Public-private partnerships: perspectives on purposes, publicness, and good governance. Public Administration and Development, 31(1), 2-14.

Chulanova, Z. K., Satybaldin, A. A., \& Koshanov A. K. (2019). Methodology for Assessing the State of Human Capital in the Context of Innovative Development of the Economy: a ThreeLevel Approach. Journal of Asian Finance, Economics and Business, 6(1), 321-328.

Israel, B. A., Schulz, A. J., Estrada-Martinez, L., Zenk, S. N., Viruell-Fuentes, E., Villarruel, A. M., \& Stokes, C., (2006), Engaging urban residents in assessing neighborhood environments and their implications for health. Journal Urban Health, 83(3), 523-539.

Jamali, D. (2004), Success and failure mechanisms of public private partnerships (PPPs) in developing countries. International Journal of Public Sector Management, 17(5), 414-430.

Joha, A., \& Janssen, M., (2010). Public-private partnerships, outsourcing or shared service centres? Motives and intents for selecting sourcing configurations. Transforming Government: People, Process and Policy, 4(3), 232-248.

Kalimullah, N.A., Alam, K.M.A., \& Nour, M.M.A., (2012). New public management: emergence and principles. BUP Journal, $1(1), 1-22$.

Kapsali, M. (2011). Systems thinking in innovation project management: a match that works. International Journal of Project Management, 29(4), 396-407.

Kireyeva, A. A. (2016). The Formation of Information Technology Clusters in Kazakhstan: System and Structured Approaches. Journal of Asian Finance, Economics and Business, 3(2), 5157. https://doi.org/10.13106/jafeb.2016.vol3.no2.51.

Kireyeva, A. A., Abilkayir, N. A., \& Tsoy, A. A. (2018). A Study on the Distribution of Information and High Technology Clusters: Kazakhstan's Experience. Journal Distribution of Science, 6(14), 5-15.

Kireyeva, A. A., Lakhonin, V., \& Kalymbekova, Z. (2019). Digital Transformations to Improve the Work and Distribution of the State Scholarships Programs. Journal of Distribution Science, 7(13), 41-47.

Kwak, Y. H., Chih, Y., \& Ibbs, C. W. (2009). Towards a comprehensive understanding of public private partnerships for infrastructure development. California Management Review, 51(2), 51-78. 
Mahoney, J. T., McGahan, A., \& Pitelis, C. (2009). The interdependence of private and public interests. Organization Science, 20(6), 1034-1052.

Maynard,A. (1986). Public and private sector interactions: an economic perspective. Social Science \& Medicine, 22(11), 1161-1166.

Owadally, M. I., \& Haberman, S. (2004). Efficient amortization of actuarial gains/losses and optimal funding in pension plans. North American Actuarial Journal, 8(1), 21-36

Peters, D. H., \& Muraleedharan, V. R., (2008). Regulating India's health services: to what end? What future? Social Science and Medicine, 66(10), 2133-2144

Randall, J., \& Satchell, S. (1997). An analysis of the hedging approach to modelling pension fund liabilities (Pensions Institute Discussion Paper PI-9714). Birkbeck College, University of London, London, England.

Salman, A., \& Jamil, S. (2017). Entrepreneurial Finance and its Impact on e-Business. Problems and Perspectives in Management, 15(3), 24-41.
Samaddar, S., Nargundkar, S., \& Daley, M., (2006). Interorganizational information sharing: the role of supply network configuration and partner goal congruence. European Journal of Operational Research, 174(2), 744-765.

Schemm, J., \& Legner, C., (2008). Toward the inter-organizational production formation supply chain-evidence from the retail and consumer goods industries. Journal of the Association for Information Systems, 9(4), 120-152

Weinhold, B. (2011). Assessing the Global Composite Impact of Chemicals on Health. Environmental Health Perspectives, 119(4), 162-165.

Zheng, J., Roehrich, J., \& Lewis, M. (2008). The dynamics of contractual and relational governance: Evidence from longterm public-private procurement arrangements. Journal of Purchasing \& Supply Management, 14(1), 43-54. 